\title{
キラル溶媒和剤を用いた NMRによる覚醒剤及び覚醒剂原料の立体識別法の検討
}

\author{
飯 田 基 雄, 花尻(木倉) 瑠理*
}

\section{NMR Study of the Discrimination of Enantiomers of Methamphetamine and Its Raw Materials Using Chiral Solvating Agents}

\author{
Motoo Iida and Ruri Kikura-Hanajiri* \\ Division of Pharmacognosy, Phytochemistry and Narcotics, National Institute of \\ Health Sciences; 3-25-26 Tonomachi, Kawasaki-ku, Kawasaki 210-9501, Japan.
}

(Received March 29, 2021; Accepted April 19, 2021)

\begin{abstract}
Some controlled substances, such as stimulants and narcotics, have asymmetric carbons in their molecules. Because the enantiomers do not always show the same pharmacological effects, and there are substances with different controls due to differences in their stereochemistry, a simple and unambiguous method for assessment of the composition of enantiomers is necessary. In this study, to develop a simple and rapid stereoscopic identification method for methamphetamine and its raw materials (ephedrine and pseudoephedrine), the ${ }^{1} \mathrm{H}$-NMR method was studied using three commercially available chiral solvating agents (CSAs); 1,1'-bi (2-naphthol) (BINOL), 2,2,2-trifluoro-1-(9-anthryl) ethanol (TFAE) and $\alpha$-methoxy- $\alpha$-(trifluoromethyl) phenylacetic acid (MTPA) . In addition, the accuracy of the optical purity, which was measured using samples mixed with enantiomers in various ratios, was investigated. The NMR peaks of the enantiomers were separated by adding $(R)$ - or $(S)$-form of BINOL, TFAE or MTPA to the chloroform- $d$ solution of methamphetamine, ephedrine or pseudoephedrine. A sufficient discrimination of enantiomers was obtained by adding about 10 equal amounts of each CSA to the solutions. With regard to the optical purity, it was possible to determine accurately the mixing of small amounts of enantiomers of about $5 \%$ even if the NMR peaks did not reach the baseline separation, when impurity peaks do not overlap. This method will be one of the useful techniques for the rapid and simple discrimination of enantiomers of illegal methamphetamine and its raw materials.
\end{abstract}

Key words_ chiral solvating agent; ${ }^{1} \mathrm{H}-\mathrm{NMR}$; methamphetamine; ephedrine; pseudoephedrine; chiral analysis

\section{緒言}

覚醒剤や麻薬などの規制薬物の多くには，分子内 に不斉炭素を有することから鏡像異性体が存在す る。それらは同じ生理活性を示すとは限らず，ま た, 立体化学の違いにより規制の異なる化合物も存 在することから，キラル識別は不可欠である.さら に, 絶対配置の決定は試料の異同識別においても有 用である. ${ }^{1)}$

光学純度の測定法として, クロマトグラフィーや NMR がある. ジアステレオマーへ誘導化しての分 析は, 誘導化試薬の光学純度や反応率の違いが, 正 確な分析を妨げる可能性がある。 そのため, キラル 固定相を用いる HPLC ${ }^{2)}$ や，キラルシフト試薬を

国立医薬品食品衛生研究所生薬部

*e-mail: kikura@nihs.go.jp
用いる NMR 測定法が注目されている. 3 ,4) クロマト グラフィーによるエナンチオ分離は, キラルな固定 相と 2 つエナンチオマーとの吸着作用の差に依存 するため, 置換基など構造のわずかな差によってキ ラリティーが生じている化合物では分離が困難な場 合がある。一方， NMR によるキラル識別は，キラ ルシフト試薬と 2 つのナンチオマーとの結合力の 差は必須ではなく, キラルシフト試薬との間で形成 される 2 つジアステレオ複合体の構造の違いに依 存する.

NMR によるキラル分析の特徵として, 試料にキ ラルシフト試薬を添加するだけで基質の光学異性体 を識別できるという簡便さ，標準試料に依存しない こと, 同時に構造情報も得られる可能性があるこ と, 複数のプロトンの非等価性を同時に調べること が可能であり結果の信頼性も評価できること，など が挙げられる。キラルシフト試薬として，Eu 錯体 


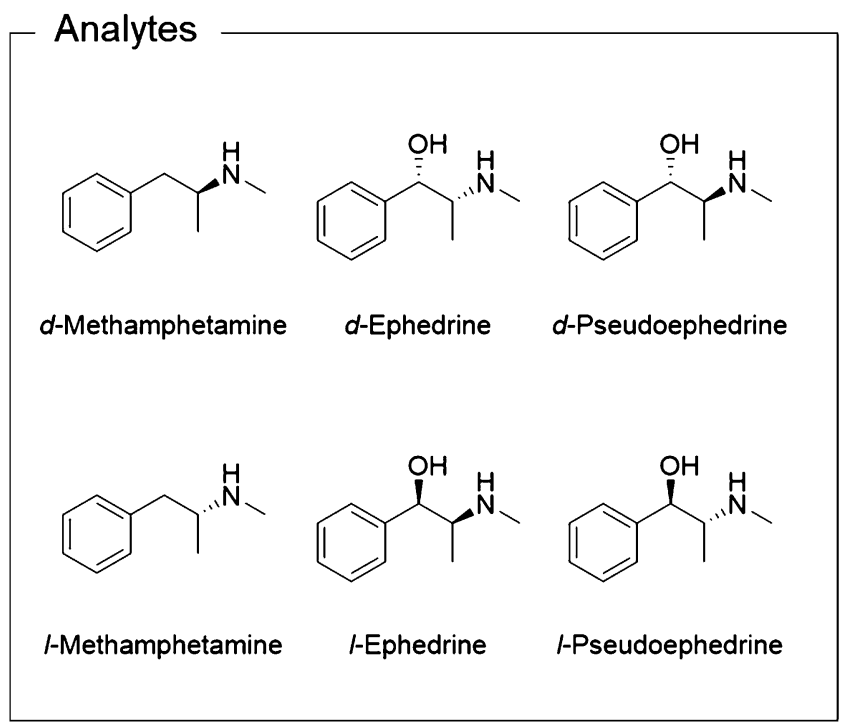

Chiral solvating agents

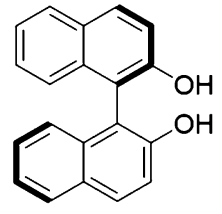

(R)-BINOL

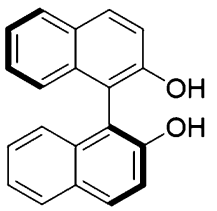

(S)-BINOL<smiles></smiles>

(R)-TFAE<smiles>OC(c1c2ccccc2cc2ccccc12)C(F)(F)F</smiles>

(S)-TFAE<smiles>COC(C(=O)O)(c1ccccc1)C(F)(F)F</smiles>

(R)-MTPA<smiles>COC(C(=O)O)(c1ccccc1)C(F)(F)F</smiles>

(S)-MTPA

Fig. 1. Chemical Structures of Methamphetamine, Ephedrine, Pseudoephedrine and Chiral Solvating Agents

などのキラルランタノイドシフト試薬（chiral lanthanide shift reagent; CLSR) を用いた識別が行われ てきたが，それら錯体は常磁性を有するため高磁場 NMR で測定すると強いブロードニングを起こすと いう問題がある．この問題を回避した反磁性のキラ ル溶媒和剤（chiral solvating agent; CSA）を用いる 方法が検討されており，2,2,2-trifluoro-1- (9-anthryl)ethanol (TFAE)を用いた Methamphetamine,5) Methylphenidate, ${ }^{6}$ Prilocaine ${ }^{7)}$ のキラル分析や, 1,1'-bi (2-naphthol)（BINOL）を用いた Mephedrone, ${ }^{8)}$ Promethazine, ${ }^{9)}$ Crispine $\mathrm{A}^{10)}$ のキラル分 析, $\alpha$-methoxy- $\alpha$-(trifluoromethyl) phenylacetic acid （MTPA）を用いた AM-1220 とAM-1220 azepaneisomer のキラル分析11)などが報告されている.

本研究では, 覚醒剤（Methamphetamine）及び 覚醒剂原料（Ephedrine, Pseudoephedrine）の簡便 な立体識別法の開発を目的として，市販されている CSA（BINOL, TFAE, MTPA）を用いた ${ }^{1} \mathrm{H}-\mathrm{NMR}$ による測定法を検討した，また，エナンチオマーを 様々な比率で混合した試料を用いて，測定した光学 純度の精度を検討した。

\section{研 究 方 法}

1. 試料及び試薬 $d$-Methamphetamine hydrochloride は大日本住友製薬株式会社製 (大阪), l-Ephedrine hydrochloride はアルプス薬品工業株式 会社製（岐阜）, $d$-Pseudoephedrine hydrochloride
及び l-Pseudoephedrine hydrochloride は Sigma-Aldrich 社製（St. Louis）を使用した。l-Methamphetamine hydrochloride 及び rac-Ephedrine hydrochloride は過去に合成した化合物 ${ }^{12)}$ を用いた。CSA は $(R)$-BINOL（Sigma-Aldrich 社製），（S)-BINOL (株式会社ダイセル社製，大阪），（R）-TFAE (Sigma-Aldrich 社製)，（S)-TFAE（東京化成工業 株式会社製，東京），(R)-MTPA（Sigma-Aldrich 及び東京化成工業株式会社製）及び（S)-MTPA （東京化成工業株式会社製）を用いた。その他の試 薬は市販特級品を使用した。 NMR 測定溶媒として Chloroform- $d$ （Sigma-Aldrich 社製）を用いた。本 研究で分析対象とした化合物及び CSA の構造を Fig. 1 に示した.

\section{2. 試料の調製}

2-1. 塩基の調製方法 マイクロチューブに各 化合物の塩酸塩をとり, 超純水 $0.5 \mathrm{~mL}$ を加えて溶 解させた. $1 \mathrm{~mol} / \mathrm{L}$ 水酸化ナトリウム水溶液又はア ンモニア水を添加して約 $\mathrm{pH} 10$ に調製し，クロロ ホルム $300 \mu \mathrm{L}$ で 2 回抽出した. クロロホルム層を 合わせ，アルゴン気流下で溶媒除去した後，減圧乾 燥した.

2-2. NMR 測定用試料 塩基とした化合物, 及び CSA をそれぞれ Chloroform- $d$ に溶解し，希 釈，混合して NMR 測定用試料を調製した. $d, l$ 混 合比を求める実験では，塩基調製操作前に濃度調整 した $d$ 体と $l$ 体の水溶液を指定の割合で混合したも 
のを使用した，デー夕解析では，分析対象化合物の 濃度を $10 \mathrm{mM}$ とみなし, スペクトルの積分比から CSA の当量, 濃度を見積もつた.

3. NMR の測定法 NMR は UltraCOOL プ ローブ付き JNM-ECZ600R/S1 (JEOL RESONANCE，東京）を使用し， $300 \mathrm{~K}$ で測定した。化 学シフトは溶媒ピーク $\left(\mathrm{CHCl}_{3}\right)$ を $7.26 \mathrm{ppm}$ に補 正した。定量実験は, 観測スペクトル幅 $20 \mathrm{ppm}$, パルス幅 $90^{\circ}$, 取り込み時間 4 秒, 遅延時間 60 秒, MPF8 による ${ }^{13} \mathrm{C}$ デカップルの条件で測定した. デー夕解析には，Delta v5.3.1（JEOL RESONANCE）及び ACD/NMR Workbook 2015.2.5 (Advanced Chemistry Development, Inc., Toronto) を用いた。

\section{研 究 結 果}

\section{1. 覚醒剂 Methamphetamine の立体識別法の検} 討 分析対象として Methamphetamine と, CSA として BINOL, TFAE, MTPA の組み合わせでエナ ンチオマーが識別できるか検討した.

$d$-, l-, rac-Methamphetamine（10 mM）にそれぞ れ $(R)$-BINOL, $(R)$-TFAE, $(R)$-MTPA $(20 \mathrm{mM}$, 2 eq.) を加えて ${ }^{1} \mathrm{H}-\mathrm{NMR}$ を測定した結果，CSA を 含まない場合と比べてピークがシフトした，そのシ フト幅は $d$ 体と $l$ 体とで異なることから, 添加した CSA が立体特異的に Methamphetamine と相互作用 することが確認できた（Supplementary material Table S1)。 また， $d$-体又は $l$-体に $(S)$-CSA を添加 して得られる化学シフトは $l$-体又は $d$-体に $(R)$ CSA を添加した場合と同一であった.

CSA を添加した場合の化学シフトは，溶液中で 平衡状態にあるフリー体と複合体それぞれの化学シ フトの加重平均で観測される．添加するCSA の当 量を増やすと, 複合体存在率が高まることで化学シ フト值の移動が大きくなると考えられる。吕そこ で，より適した分析条件を探索するため，CSAの 当量を変化させてピークシフト幅, $d$ 体と $l$ 体との シフト差を調べた（Supplementary material Tables S2-S4，Figs. S1-S3). BINOL 及び TFAE を用いた 場合, 添加当量を増やす程ピークのシフト幅も大き くなる傾向があるが, $d$ 体と $l$ 体とのシフト差は 10 当量程度で飽和しつつあつた (Figs. 2 and 3 )。一 方, MTPA を用いた場合では, 4 当量程度の添加

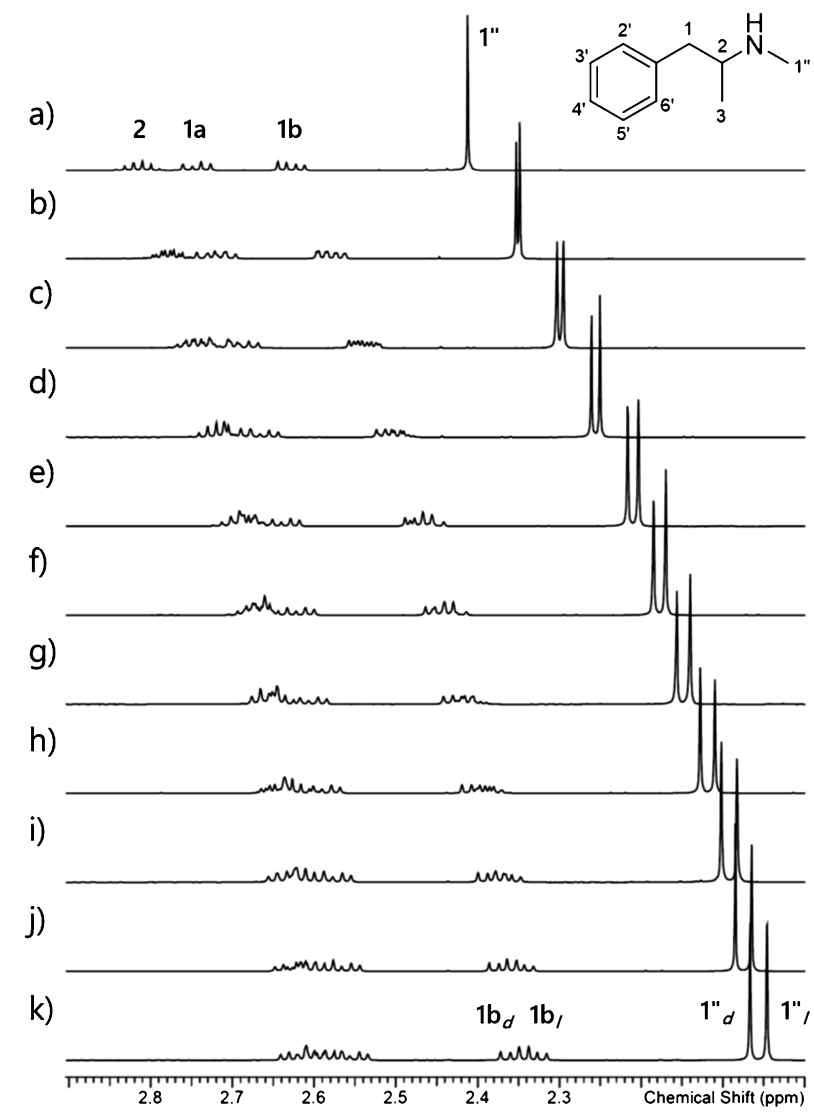

Fig. 2. Selected Expansion of the ${ }^{1} \mathrm{H}$ Spectra of Methamphetamine $(10 \mathrm{mM})$ with/without $(R)$-BINOL $(600 \mathrm{MHz}$, $\mathrm{CDCl}_{3}, 300 \mathrm{~K}$ )

a) $d$-methamphetamine, $r a c$-methamphetamine with $(R)$-BINOL; b) 1.1 eq., c) 2.05 eq., d) 3.05 eq., e) 4.25 eq., f) 5.4 eq., g) 6.6 eq., h) 8 eq., i) 9.4 eq., j) 10.2 eq., k) 11.4 eq.

からシフト幅が一定になる傾向があった．当量を増 やすとシフト差が小さくなるプロトン（H-3, H-1") やピークがブロードになるプロトン（H-1"） はあったが，シフト差の大きい H-1a では，BINOL 及び TFAE と同様, シフト差は 10 当量程度で飽和 しつつあつた.

以上の結果を踏まえて, CSA の添加量をシフト 差がほぼ飽和する 10 当量に設定し, $d, l$ 混合比を 変化させた場合に光学純度がどの程度の精度で測定 できるかを検討した，塩基調製操作前に $d$ 体と $l$ 体 を指定の割合で混合し，NMR 測定は定量条件（又 ピンなし／あり）を用いた（Fig. 4, Supplementary material Figs. S4-S6)。積分值は, シグナル分離の よいプロトン（BINOL: H-1", TFAE: H-2' ${ }^{\prime} 6^{\prime}$, MTPA: H-1a) について, 垂直分割, 接線補間及び 波形分離の 3 通りの方法で求めて比較した（Table 1, Supplementary material Tables S5 and S6). NMR 

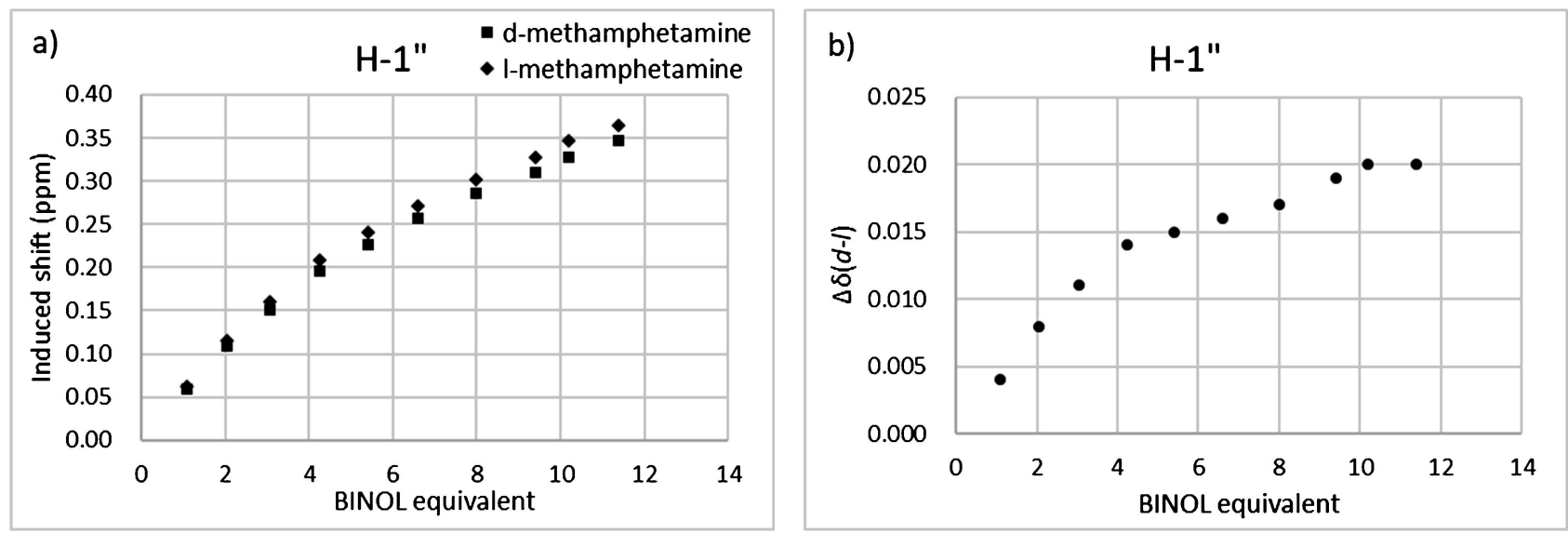

Fig. 3. Influence of $(R)$-BINOL Equivalents on Chemical Shifts of Methamphetamine a) Induced shift, $\Delta \delta$ of $d$ - and $l$-methamphetamine, b) chemical shift difference, $\Delta \delta_{(d-l)}$ of rac-methamphetamine.

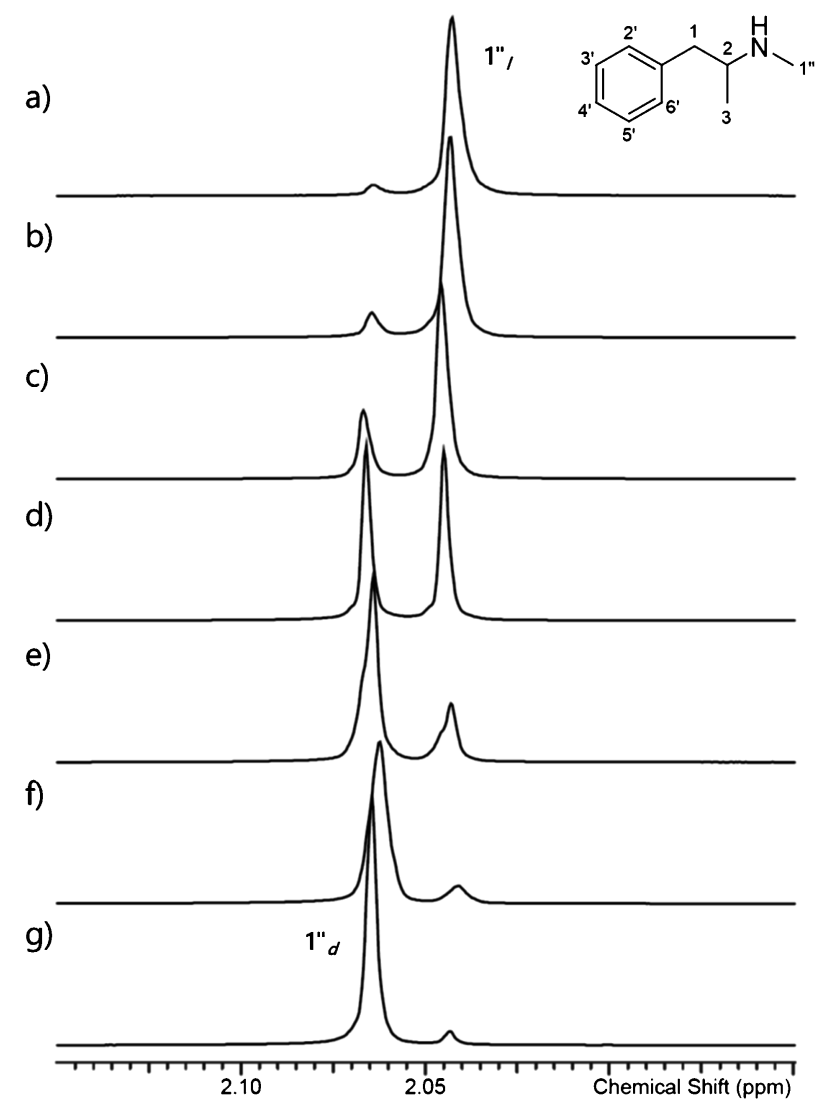

Fig. 4. Selected Expansion of the ${ }^{1} \mathrm{H}$ Spectra of Mixtures of $d$ - and $l$-Methamphetamine $(10 \mathrm{mM})$ with $(R)$-BINOL $(600$ $\mathrm{MHz}, \mathrm{CDCl}_{3}, 300 \mathrm{~K}$, spin off)

a) $d / l=5 / 95$ with 11.5 eq. of $(R)$-BINOL, b) $d / l=10 / 90$ with 11 eq. of $(R)$-BINOL, c) $d / l=25 / 75$ with 10.6 eq. of $(R)$-BINOL, d) $d / l=50 /$ 50 with 10.7 eq. of $(R)$-BINOL, e) $d / l=75 / 25$ with 10.6 eq. of $(R)$ BINOL, f) $d / l=90 / 10$ with 11.1 eq. of $(R)$-BINOL, g) $d / l=95 / 5$ with 11.1 eq. of $(R)$-BINOL.
ピークは裾野が広いローレンツ曲線として観測され るため，本実験条件では，一見ピークが離れている ようでもべースラインに至るほどの分離とはならな かった。 そのため，垂直分割により積分值を求めた 場合に，割合の小さいピークの積分值が過大に見積 もられる傾向が，また接線補間による場合には，過 少に見積もられる傾向があった。一方，波形分離を 用いた場合では，広い範囲で，実際の調製割合との 差が数\%以内と比較的精度のよい結果が得られた. 測定時のスピンの有無に関して，定量測定では一般 にスピニングサイドバンド（spinning side band; SSB）による誤差要因を避けるためにスピンさせな いで測定するが，本実験ではスピンさせた方がやや 良好な結果が得られた。これは，SSBによる悪影 響よりも，スピンによるシム改善，ピーク形状の改 善が精度向上に寄与したと考えられる。

2. 覚醒剂原料への適用 Ephedrine 及び Pseudoephedrine に対しても，（R)-, $(S)$-CSA （BINOL, TFAE, MTPA）を 10 当量添加する条件 で立体異性体が識別できるか検討した．本実験のす べての組み合わせにおいて，立体異性体を識別でき るだけの化学シフト差が観測され，特にBINOL を 用いた場合に $N$-メチルプロトン (H-1") $)$ の化学シ フト差が大きかった (Figs. 5 and 6, Supplementary material Tables S7 and S8).

ラセミ体の覚醒剤等に対して $R$ 体の CSA を 10 当量添加した場合に想定される化学シフト差 $\left(\Delta \delta_{(d-l)}\right)$ を Fig. 7 にまとめた $[d$-体又は $l$-体に $(R)$ CSA を添加して得られる化学シフトは $l$-体又は 
Table 1. Analytical Results of Mixtures of $d$ - and $l$-Methamphetamine in Various Ratios by ${ }^{1} \mathrm{H}$-NMR Using $(R)$-BINOL a,b

\begin{tabular}{|c|c|c|c|c|c|c|c|c|c|c|c|c|}
\hline \multirow{3}{*}{$d_{\mathrm{p}}$} & \multicolumn{6}{|c|}{ Spin off c } & \multicolumn{6}{|c|}{ Spin $(15 \mathrm{~Hz})^{c}$} \\
\hline & \multicolumn{2}{|c|}{$\begin{array}{l}\text { Vertical } \\
\text { partition }\end{array}$} & \multicolumn{2}{|c|}{$\begin{array}{c}\text { Tangent } \\
\text { interpolation }\end{array}$} & \multicolumn{2}{|c|}{ Curve fitting } & \multicolumn{2}{|c|}{$\begin{array}{l}\text { Vertical } \\
\text { partition }\end{array}$} & \multicolumn{2}{|c|}{$\begin{array}{c}\text { Tangent } \\
\text { interpolation }\end{array}$} & \multicolumn{2}{|c|}{ Curve fitting } \\
\hline & $d_{\mathrm{m}}$ & $\Delta d$ & $d_{\mathrm{m}}$ & $\Delta d$ & $d_{\mathrm{m}}$ & $\Delta d$ & $d_{\mathrm{m}}$ & $\Delta d$ & $d_{\mathrm{m}}$ & $\Delta d$ & $d_{\mathrm{m}}$ & $\Delta d$ \\
\hline 5 & 11.3 & 6.3 & 3.2 & -1.8 & 4.2 & -0.8 & 10.1 & 5.1 & 4.0 & -1.0 & 5.9 & 0.9 \\
\hline 10 & 13.9 & 3.9 & 7.4 & -2.6 & 9.5 & -0.5 & 13.9 & 3.9 & 7.9 & -2.1 & 10.6 & 0.6 \\
\hline 25 & 27.0 & 2.0 & 20.5 & -4.5 & 24.8 & -0.2 & 27.9 & 2.9 & 20.7 & -4.3 & 25.7 & 0.7 \\
\hline 50 & 51.3 & 1.3 & 51.4 & 1.4 & 50.3 & 0.3 & 50.7 & 0.7 & 51.0 & 1.0 & 50.1 & 0.1 \\
\hline 75 & 73.8 & -1.2 & 80.0 & 5.0 & 76.3 & 1.3 & 74.9 & -0.1 & 79.3 & 4.3 & 75.1 & 0.1 \\
\hline 90 & 87.8 & -2.2 & 92.6 & 2.6 & 92.3 & 2.3 & 88.0 & -2.0 & 92.2 & 2.2 & 90.4 & 0.4 \\
\hline 95 & 91.9 & -3.1 & 96.4 & 1.4 & 95.4 & 0.4 & 92.4 & -2.6 & 96.2 & 1.2 & 95.2 & 0.2 \\
\hline
\end{tabular}

The H-1" peaks were chosen for integration. $d_{\mathrm{p}}$ : Ratios (\%) of $d$-methamphetamine expected after preparation, $d_{\mathrm{m}}$ : Ratios $(\%)$ of $d$-methamphetamine measured experimentally by three integration methods (vertical partition, tangent interpolation or curve fitting), $\Delta d$ : Different values between $d_{\mathrm{m}}(\%)$ and $d_{\mathrm{p}}(\%)$. a Total concentration of methamphetamine was $10 \mathrm{mM}$; the concentration of $(R)$-BINOL was $c a .100 \mathrm{mM}$. ${ }^{\mathrm{b}} \mathrm{Recorded}^{\mathrm{at}} 600 \mathrm{MHz}$ in $\mathrm{CDCl}{ }_{3}$ at $300 \mathrm{~K}$. ${ }^{\mathrm{c}} \mathrm{NMR}$ data was collected without spinning the tube or with spinning at $15 \mathrm{~Hz}$.

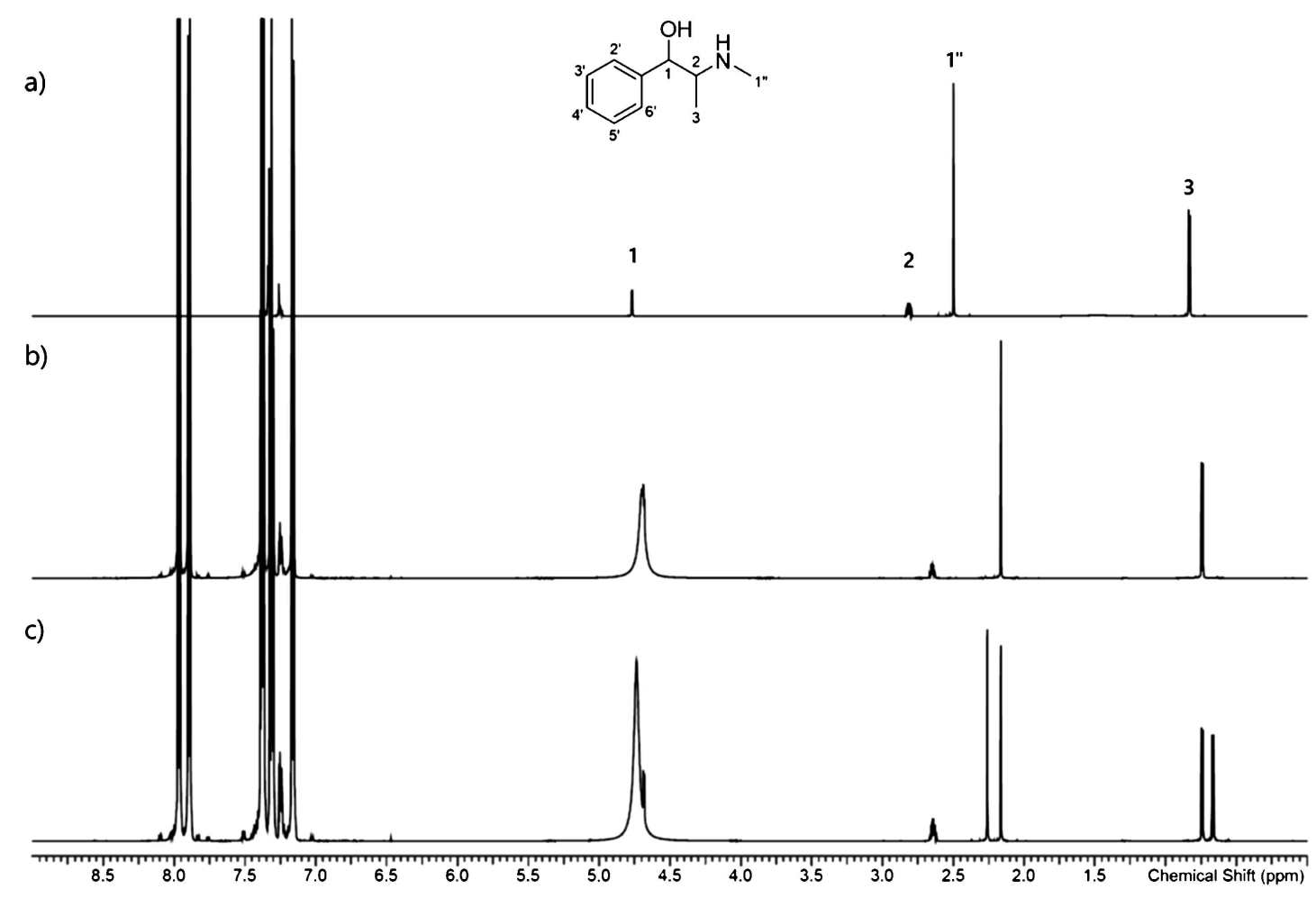

Fig. 5. ${ }^{1} \mathrm{H}$ Spectra of Ephedrine (10 mM) with/without $(R)$-BINOL $\left(600 \mathrm{MHz}, \mathrm{CDCl}_{3}, 300 \mathrm{~K}\right)$ a) $r a c$-ephedrine, b) $l$-ephedrine with 11 eq. of $(R)$-BINOL, c) rac-ephedrine with 11.2 eq. of $(R)$-BINOL.

$d$-体に $(S)$-CSA を添加した場合と同一であり，(S) CSA を用いた実験データも計算に用いた]。これは, $d$ 体の覚醒剂等に対して $R$ 体若しくは $S$ 体の CSA を添加した場合に想定される化学シフト差 $\left(\Delta \delta_{(R-S)}\right)$ と言い換えることもできる.
考察

CSA を添加した際のピーク位置（絶対值）は, 濃度や添加した CSA の当量, 残留水分や塩などの 夾雑物により影響を受けるため, ピークのシフト值 だけで立体化学を帰属することは避けた方が望まし い. 一方, $d$ 体と $l$ 体のシフト差の符号（相対位置） 


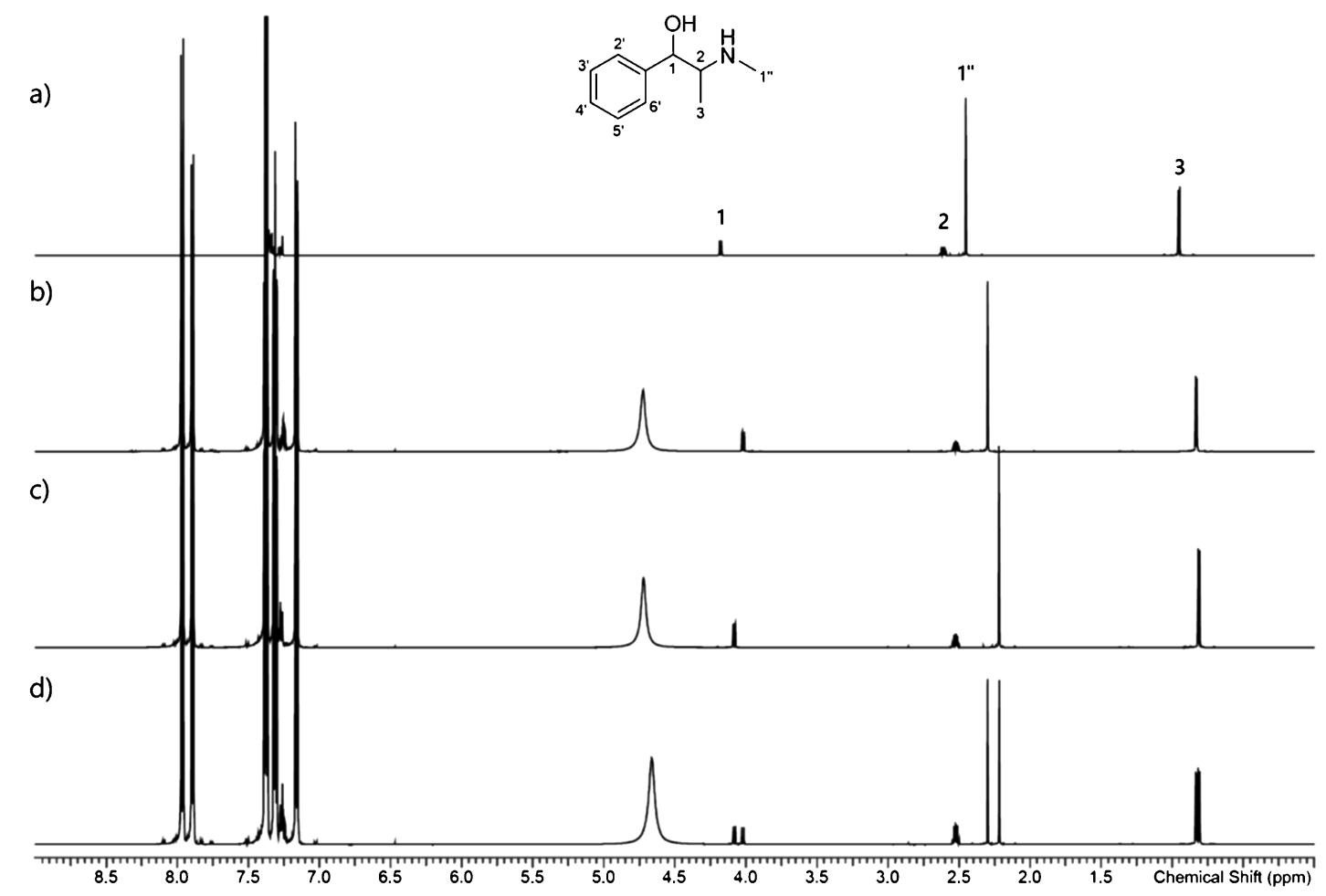

Fig. 6. ${ }^{1} \mathrm{H}$ Spectra of Pseudoephedrine $(10 \mathrm{mM})$ with/without $(R)$-BINOL $\left(600 \mathrm{MHz}, \mathrm{CDCl}_{3}, 300 \mathrm{~K}\right)$ a) $l$-pseudoephedrine, b) $d$-pseudoephedrine with 10.4 eq. of $(R)$-BINOL, c) $l$-pseudoephedrine with 9.5 eq. of $(R)$-BINOL, d) rac-pseudoephedrine with 10.2 eq. of $(R)$-BINOL .

Methamphetamine

Fig. 7. Chemical Shift Differences between $d$ - and $l$-Compounds $(10 \mathrm{mM})$ with $(R)$-CSA (ca. 10 eq.) $\left(600 \mathrm{MHz}, \mathrm{CDCl}_{3}, 300 \mathrm{~K}\right)$ 
は, 添加した CSA の当量によって変わらなかっ た。したがって，CSA を添加したスペクトルにお

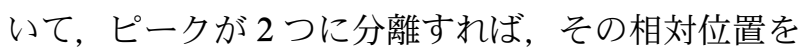
Fig. 7 の值と比較して立体化学を帰属することが可 能である [Fig. 8(a)]。単一ピークの場合は, でき るだけ濃度・当量などの条件をそろえて両エナンチ オマーの CSA 添加試料を測定し, 測定試料間で ピーク位置を比較することで立体化学を帰属するこ とができる [Fig. 8(b)]. また，両エナンチオマー を添加してもピーク位置に差が出なかった場合は, この実験が適応できないという判断ができ, 自己 チェック機能も備わった手法と言える.

近年, CSA 添加試料の NMR によるキラル識別 は，危険ドラッグに含まれる主成分の立体化学を検 討する上でも使用されている，危険ドラッグは，次 々と構造類似化合物が市場に出現し, 分析用標品の 入手が困難である場合がある，また，違法に流通す る危険ドラッグの立体化学については明らかになつ ていないことが多い. Stolarskaらは, Mephedrone 等の合成力チノン類について, CSA として $(R)$ BINOL を使用した NMR によるキラル識別法の検 討を行っている. ${ }^{8)}$ また, Langer らは, 危険ドラッ グ製品（乾燥植物細片製品）から，数種類のカンナ ビノイド受容体に作用する合成化合物（合成カンナ ビノイド）を検出・同定している，そして，同定し た化合物のうち，構造中に不斉炭素を有する合成力 ンナビノイド AM-1220 及び AM-1220 azepaneisomer について, CSA として 1 当量の $(R)$-MTPA を添加した試料の NMR 測定を行い, 両化合物の市 場流通品がラセミ体であることを示している. ${ }^{11)} こ$ のように, CSA 添加試料の NMR によるキラル識 別法は, 市場に流通する危険ドラッグに含まれる構 造既知である主成分の立体化学を簡便かつ迅速に推 測する上でも有用な手法になり得ると考えられる.

\section{結論}

覚醒剂（Methamphetamine）及び覚醒剂原料 (Ephedrine, Pseudoephedrine) にCSA（BINOL, TFAE，MTPA）を添加することで，立体異性体の NMR ピークが分離することを確認した．CSA 添 加量を変化させて調べた結果，シフト差は 10 当量 でほぼ飽和し，十分な立体識別能が得られることが 分かった. また, 光学純度に関して, 不純物ピーク a)

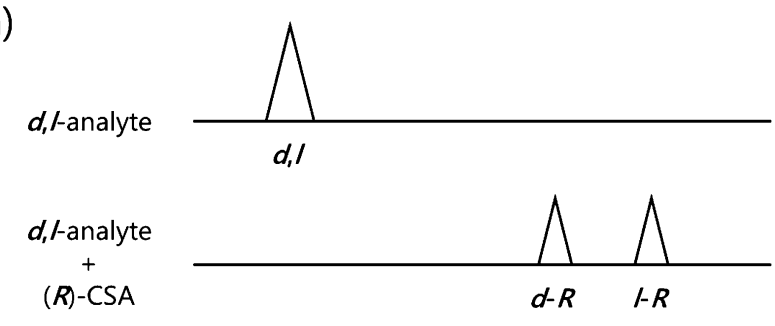

b)

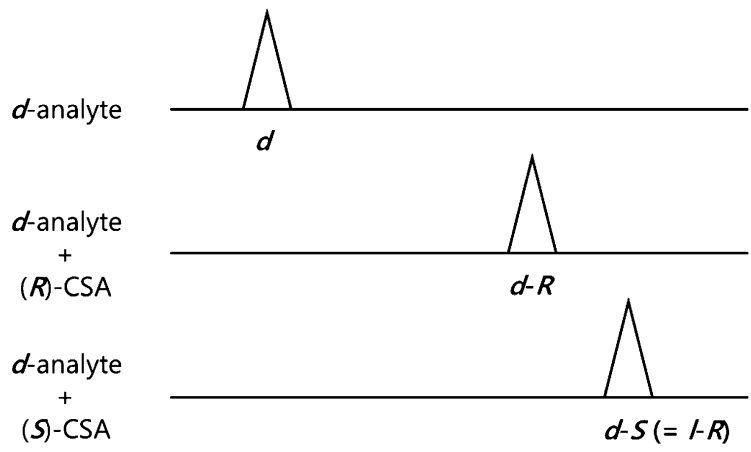

Fig. 8. Conceptual Diagram of the Discrimination of Enantiomers by NMR Using a Chiral Solvating Agent

a) For a mixture of $d$-and $l$-compounds, b) for an enantiopure compound.

が重ならない場合は, ベースライン分離まで達して いなくても裾野が少し重なる程度のピーク分離であ れば，波形分離処理にて積分をとることで，5\%程 度の少量エナンチオマーの混在を精度よく求めるこ とが可能であった。本手法は，違法に流通する覚醒 剂や覚醒剤原料の立体化学を迅速かつ簡便に検討す る上で，有用な手法の 1 つと考えられる，また，他 のアミン系薬物の立体識別にも適用できる可能性が あり，更なる検証が望まれる.

謝辞本研究は厚生労働科学研究費補助金（医 薬品・医療機器等レギュラトリーサイエンス政策研 究事業）で行われたものであり，関係各位に深謝い たします。

利益相反＼cjkstart開示すべき利益相反はない.

Supplementary materials この論文のオンライ ンに Supplementary materials（電子付録）を含ん でいる.

\section{REFERENCES}

1) Iwata Y. T., Kuwayama K., Tsujikawa K., Kanamori T., Inoue H., Bunseki Kagaku, 63, 
221-231 (2014) .

2) Castrignanò E., Lubben A., Kasprzyk-Hordern B., J. Chromatogr. A, 1438, 84-99 (2016).

3) Uccello-Barretta G., Balzano F., Top. Curr. Chem., 341, 69-131 (2013).

4) Yang L., Wenzel T., Williamson R. T., Christensen M., Schafer W., Welch C. J., ACS Cent. Sci., 2, 332-340 (2016).

5) Hanna G. M., Pharmazie, 61, 188-193 (2006).

6) Hanna G. M., Lau-Cam C. A., J. Pharm. Biomed. Anal., 11, 665-670 (1993).

7) Hanna G. M., Enantiomer, 5, 303-312 (2000).
8) Stolarska M., Bocian W., Sitkowski J., Naumczuk B., Bednarek E., Poplawska M., Błażewicz A., Kozerski L., J. Mol. Struct., 1219, 128575 (2020).

9) Borowiecki P., Tetrahedron: Asymmetry, 26, 16-23 (2015)

10) Yuste F., Sánchez-Obregón R., Díaz E., García-Carrillo M. A., Tetrahedron: Asymmetry, 25, 224-228 (2014).

11) Langer N., Lindigkeit R., Schiebel H. M., Ernst L., Beuerle T., Drug Test. Analysis, 6, 59-71 (2014).

12) Kikura R., Ishigami A., Nakahara Y., Jpn. J. Toxicol. Environ. Health, 38, 136-141 (1992). 